\title{
Effects of the polyhistidine tag on kinetics and other properties of trehalose synthase from Deinococcus geothermalis
}

\author{
Anna Panek, Olga Pietrow, Paweł Filipkowski and Józef Synowiecki ${ }^{\bowtie}$ \\ Department of Food Chemistry, Technology and Biotechnology, Faculty of Chemistry, Gdansk University of Technology, Gdańsk, Poland
}

\begin{abstract}
Two recombinant trehalose synthases from Deinococcus geothermalis (DSMZ 11300) were compared. A significant influence of the artificial polyhistidine tag was observed in protein constitution. The recombinant trehalose synthase from D. geothermalis with $\mathrm{His}_{6}$-tag has a higher $K_{\mathrm{m}}$ value of $254 \mathrm{mM}$, in comparison with the wild-type trehalose synthase $\left(K_{\mathrm{m}} 170 \mathrm{mM}\right)$, and displayed a lower activity of maltose conversion when compared to the wild type. Moreover, differences in properties like temperature, $\mathrm{pH}$, thermal- and pH-stability were observed. Presence of the histidine tag caused a decrease of thermal resistance in case of trehalose synthase with $\mathrm{His}_{6}$-tag. These data confirmed a suggestion that the introduction of the histidine domain produces in some seldom cases undesirable changes in the protein.
\end{abstract}

Key words: Deinococcus geothermalis, trehalose synthase, influence of $\mathrm{His}_{6}$-tag, trehalose, gene expression, Escherichia coli

Received: 23 November, 2012; revised: 25 April, 2013; accepted: 14 May, 2013; avaialble on-line: 06 June, 2013

\section{INTRODUCTION}

Trehalose $(\alpha$-D-glucopyranosyl-1,1- $\alpha$-D-glucopyranoside) is a stable non-reducing disaccharide, which can be used in food, cosmetics, medical, and biotechnological industries, as well as for the stabilization of vaccines, enzymes, antibodies, hormones, pharmaceutical preparations, and organs for transplantations (Richards et al., 1991; Higashiyama 2002; Berendsen 2002). Trehalose can create hydrogen bonds with protein and lipids, which stabilize their molecules and biological membranes (Lins et al., 2004; Jain and Roy, 2008). Moreover, the formation of amorphous glass protects biological molecules during desiccation, freezing, heating, and oxidation (Crove and Crove, 2002; Banaroudi et al., 2001).

Enzymes responsible for the one-step production of trehalose from maltose are trehalose synthases, EC 5.4.99.16. This process employs an inexpensive substrate derived from starch. Trehalose synthases are also characterized by amylase activity that converts glycogen into trehalose (Pan et al., 2008). Trehalose synthases have been identified as sources of such bacteria as for instance the Pseudomonas putida, Meiothermus ruber, Thermus thermophilus, Deinococcus radiodurans and Arthobacter aurescens (Ma et al., 2006; Zdziebło \& Synowiecki, 2006; Xiuli et al., 2009; Filipkowski et al., 2012; Zhu et al., 2008).

In our previous work, as a new source of trehalose synthase, we used the extremophilic bacteria, D. geothermalis (Filipkowski et al., 2012). This microorganism is a red-pigmented, Gram-positive, non-pathogenic, moderate thermophile extremely resistant to ionizing radiation, ultraviolet light, and desiccation (Ferreira et al., 1997). In our study, the gene encoding the trehalose synthase from D. geothermalis was cloned and expressed in Escherichia coli. This recombinant enzyme contains the His tag, which simplified the enzyme purification using immobilized metal affinity chromatography (IMAC). The method for puryfing proteins with histidine residues was first described by Hochuli et al. (1987). IMAC is based on the interaction between transitional metal ions, eg., $\mathrm{Cu}^{2+}, \mathrm{Co}^{2+}$, or $\mathrm{Ni}^{2+}$, immobilized on a matrix in a gelling agent, such as agarose or derivatized silica gel and proteins. The main amino acid in proteins that interacts with the immobilized transitional metal ions is histidine. Nowadays, more than 100 structures of His-tagged proteins have been deposited in the Protein Data Bank. In some seldom cases the affinity tag may interfere with protein activity (Wu \& Filutowicz, 1999; Terpe, 2003). Usually, the fusion enzymes are as active as in case of wild proteins. However, in some cases the $V_{\max }$ for the tagged enzymes is $50 \%$ of the wild-type. Lowered activities are caused by insoluble inclusion bodies, misfolded conformation when expressed in E. coli, or different dimerization/oligomerization properties (Halliwell et al., 2001; Pietzsch et al., 2000; Wu \& Filutowicz, 1999).

The previously obtained recombinant trehalose synthase from the $D$. geothermalis containing the polyhistidine domain had decreased the affinity to maltose. The purpose of this study was to produce a trehalose synthase destitute of histidine residues. Kinetic parameters between the wild-type enzyme and the recombinant protein with the polyhistidine tag were examined to compare their properties.

\section{MATERIALS AND METHODS}

Bacterial strains, plasmids, and culture conditions. D. geothermalis (DSMZ 11300, Braunschweig, Germany) was used as a source of the trehalose synthase gene. Bacterial cells were cultivated aerobically on a rotary shaker (Forma Orbital, Thermo Scientific, Marietta, OH, US) at $45^{\circ} \mathrm{C}(\mathrm{pH} 7.2)$ in a modified medium recommended by the DSMZ as described previ-

\footnotetext{
$\triangle$ e-mail: jozsynow@pg.gda.pl
}

Abbreviations: $K_{m}$ Michaelis constant, $V_{\max }$ maximum rate, DgeoTreS, trehalose synthase from D. geothermalis with $\mathrm{His}_{6}$-tag, DgeoTresw, trehalose synthase from D. geothermalis wild type, DSMZ, Deutsche Sammlung von Mikroorganismen und Zellkulturen, $C D$, Circular dichroism spectroscopy $\mathrm{OD}_{600}$, optical density at $\lambda=600 \mathrm{~nm}, \mathrm{PCR}$, polymerase chain reaction, DNA, deoxyribonucleic acid, EDTA, ethylenediaminetetraacetic acid, HPLC, high-performance liquid chromatography, SDS/PAGE, sodium dodecyl sulfate polyacrylamide gel electrophoresis 
ously (Filipkowski et al., 2006, Ferreira et al., 1997). The E. coli TOP10F' (Invitrogen, Carlsbad, CA) and Rosetta (DE3)pLysS (Novagen, Nottingham, United Kingdom) strains were used as a cloning host and an expression host, respectively. The $E$. coli cells with plasmids were cultured aerobically at $37^{\circ} \mathrm{C}$ to $\mathrm{OD}_{600}$ of 0.6 in an LB medium supplemented with tetracycline $(12.5 \mu \mathrm{g} / \mathrm{mL})$ or chloramphenicol $(34 \mu \mathrm{g} / \mathrm{mL})$, respectively. The cells were harvested by centrifugation at $3000 \times g$ for $10 \mathrm{~min}$. The pJET (Fermentas UAB, Vilnius, Lithuania) and pET30Ek/LIC (Novagen, Darmstadt, Germany) plasmids were used for the construction of the expression system. Restriction enzymes were purchased from Fermentas.

Amplification of trehalose synthase (DgeoTreSW) gene. DNA from D. geothermalis isolated using a genomic DNA preparation kit (A\&A Biotechnology, Gdańsk, Poland) was used for polymerase chain reaction (PCR) amplification with the following two primers:

\section{5' aaaCATATGACGCAAACCTCCACCTCCGAGT 3', and 5' tatCTCGAGTTACCGCACCCCCGACAGC 3'}

containing underlined recognition sites for restriction endonucleases, NdeI and XhoI (Fermentas, Lithuania). The reaction was performed using 250 ng of DNA, 10 pmoles of each primer, $12 \mu$ moles of dNTPs, 12.5 $\mu \mathrm{L} 2 \times$ PCR buffer $\left(5 \mathrm{mM} \mathrm{MgCl}_{2}, 100 \mathrm{mM}\right.$ Tris, $\mathrm{pH}$ 9.0, $40 \mathrm{mM}\left(\mathrm{NH}_{4}\right)_{2} \mathrm{SO}_{4}, 10 \mathrm{mM}$ DMSO) and $0.5 \mu \mathrm{L}$ Marathon DNA polymerase (Pwo \& Taq polymerase mixture). After $1 \mathrm{~min}$ of preliminary heating at $95^{\circ} \mathrm{C}$ in a thermal cycler (EpGradient S, Eppendorf, Hamburg, Germany), each of 30 cycles was conducted 5 -times at $95^{\circ} \mathrm{C}$ for $1 \mathrm{~min}$, at $59^{\circ} \mathrm{C}$ for $1 \mathrm{~min}$ and at $72^{\circ} \mathrm{C}$ for $2 \mathrm{~min}$, then 25 -times at $95^{\circ} \mathrm{C}$ for $1 \mathrm{~min}$, at $67^{\circ} \mathrm{C}$ for $1 \mathrm{~min}$ and at $72^{\circ} \mathrm{C}$ for $1.5 \mathrm{~min}$, with a final step of $5 \mathrm{~min}$ at $72^{\circ} \mathrm{C}$. The DNA fragment encoding DgeoTreSW was obtained and cloned into pJET vector following the steps described by the producer of the CloneJet kit (Fermentas). After sequencing and confirming the proper sequence, the DNA construct was digested with $N d e I$ and $X h o I$ restriction endonucleases and resubcloned into a pET30Ek/LIC vector. The digestion product, approximately below $1,700 \mathrm{bp}$, was isolated from an agarose gel bands using the Gel-Out kit (A\&A Biotechnology).

Construction of expression vector. The competent cells E. coli TOP10F' suspended in $1 \mathrm{~mL} 100 \mathrm{mM} \mathrm{CaCl}_{2}$ were transformed by the ligation mixture for $1 \mathrm{~h}$ at $8^{\circ} \mathrm{C}$, and after a heat shock $\left(1.5 \mathrm{~min}\right.$ at $42^{\circ} \mathrm{C}$, then $1.5 \mathrm{~min}$ at $4^{\circ} \mathrm{C}$ ) were incubated for $1 \mathrm{~h}$ at $37^{\circ} \mathrm{C}$ in $400 \mu \mathrm{L}$ SOC medium (Invitrogen). The transformed E. coli cells plated on LB-agar tetracycline/kanamycin (tetracycline as described previously, kanamycin $20 \mu \mathrm{g} / \mathrm{mL}$ ) plates were incubated at $37^{\circ} \mathrm{C}$. After $16-18 \mathrm{~h}$ of growth, the obtained colonies were examined for the presence of trehalose synthase gene of $D$. geothermalis by PCR amplification and restriction analysis. The authenticity of the clone was ascertained by sequencing of the complete DNA fragment. The obtained construction, designated as pET30Ek/ LICDgeo TreSW, was isolated and selected by electrophoresis on $1 \%$ agarose gel and then transformed into E. coli Rosetta (DE3)pLysS cells.

Expression of the wild-type trehalose synthase. A single colony of transformed E. coli from LB-agar plates was inoculated in a $50 \mathrm{~mL}$ liquid LB medium, supplemented with kanamycin/chloramphenicol, and cultivated at $37^{\circ} \mathrm{C}$. When the $\mathrm{OD}_{600}$ reached the value of about 0.6, the cell suspension was transferred to 2 L of LB medium containing kanamycin/chloram- phenicol. The cultures were grown up to $\mathrm{OD}_{600}$ of 0.6 at conditions described above. Then, the DgeoTreS expression in E. coli Rosetta (DE3)pLysS was induced at $37^{\circ} \mathrm{C}$ with isopropyl $\beta$-D-thiogalactopyranoside (IPTG) at the final concentration of $1 \mathrm{mM}$. The cells were harvested $3 \mathrm{~h}$ after induction by centrifugation, and the pellet washed with distilled water was centrifuged and stored at $-20^{\circ} \mathrm{C}$ until use. SDS/PAGE separation of proteins was performed according to the method of Leammli (1970). The samples $(10 \mu \mathrm{L})$ denatured by $\beta$-mercaptoethanol as a reducing agent and SDS were layered on the gel and separated using a voltage gradient of $15 \mathrm{~V} / \mathrm{cm}$. Protein bands were located by stained with Coomassie Brillant Blue R250.

Isolation and purification of recombinant trehalose synthase. The transformed E. coli cells, harvested from $2 \mathrm{~L}$ of induced culture, were sonicated at $20 \mathrm{kHz}$ (three times for $10 \mathrm{~s}$ in $30 \mathrm{~s}$ intervals) in $80 \mathrm{~mL} 10 \mathrm{mM}$ phosphate buffer ( $\mathrm{pH}$ 7.6) containing $1 \mathrm{M}$ EDTA, $100 \mathrm{mM} \mathrm{CaCl}_{2}, 0.1 \mathrm{mg}$ lysozyme, and 1 mg RNase, using the Brenson Ultrasonic Sonifier II W250D (Geneve, Switzerland). The resulting mixture was centrifuged at $9000 \times g$ for $40 \mathrm{~min}$ to give a clear supernatant. The protein fraction with trehalose synthase activity was precipitated by $\left(\mathrm{NH}_{4}\right)_{2} \mathrm{SO}_{4}$ to a final concentration of $20 \%(\mathrm{w} / \mathrm{v})$. The centrifuged precipitate $(9000 \times g, 15 \mathrm{~min})$ was dissolved in a small volume of citrate-phosphate buffer $\mathrm{pH}$ 7.2. Then, this fraction was purified, concentrated on the Centrifugal Filter Device (Amicon ${ }^{\circledR}$ Ultra-15 50000 MWCO Carrightwohill, Cork, Ireland), and after changing the buffer to physiological salt, used as a final preparation of the enzyme.

Enzyme assay. The activity of DgeoTreSW was determined by measuring the trehalose produced from maltose. The assays were initiated by the addition of $0.25 \mathrm{~mL}$ of Dgeo'TreSW solution to $1.0 \mathrm{~mL}$ of $0.3 \mathrm{M}$ maltose solution in a $50 \mathrm{mM}$ Britton-Robinson buffer ( $\mathrm{pH}$ 7.6). The reaction at $40^{\circ} \mathrm{C}$ was terminated after heating the sample at $100^{\circ} \mathrm{C}$ for $10 \mathrm{~min}$. The samples purified by centrifugation $(9000 \times g$ for $10 \mathrm{~min})$ and filtration on a $0.2 \mu \mathrm{m} \mathrm{Chromafil}^{\circledR}$ PEF 20/25 filter (Machery-Nagel GmbH, Duren, Germany) were passed through a APS-2 HYPERSIL column (Thermo Electron Corporation, Dreiech, Germany) using acetonitrile/methanol/water (78:11:11, v/v/v) as mobile phase at a flow rate of $1.8 \mathrm{~mL} / \mathrm{min}$. The column temperature was $30^{\circ} \mathrm{C}$. The amounts of the products formed during conversion of maltose were calculated from the area of the peaks obtained after sample separation by HPLC using a refractive index detector (La Chrom-7490, Merck, Hitachi, Tokyo, Japan). Trehalose, maltose, and glucose were used as standards at concentrations of $10 \mathrm{mg} / \mathrm{mL}$.

The DgeoTreSW activity was expressed as the amount of enzyme that produces $1 \mu \mathrm{mol}$ of trehalose per minute under described conditions. The relative enzyme activity $(\%)$ was defined as the percentage of enzyme activity in the control.

The temperature dependence of enzyme activity was assayed within the range of $5-70^{\circ} \mathrm{C}$. The thermal stability of trehalose synthase was investigated by incubation of the enzyme solution in $50 \mathrm{mM}$ BrittonRobinson buffer ( $\mathrm{pH} 7.6$ ) at $40^{\circ} \mathrm{C}, 55^{\circ} \mathrm{C}$, and $60^{\circ} \mathrm{C}$ for different periods (up to $8 \mathrm{~h}$ ). Protein concentrations $(\mathrm{mg} / \mathrm{mL})$ were determined by the measurement of absorbance at 280 using a Nano-Drop spectrophotometer (Thermo Fisher Scientific Inc. Wilmington, DE, US). 


\section{RESULTS AND DISCUSSION}

\section{Molecular cloning and characterization of His-tag free DgeoTresW}

Our previous experiments indicate that the recombinant trehalose synthase from $D$. geothermalis possessing His $_{6}$-tag (Dgeo'TreS) had decreased the affinity to maltose, and the $K_{\mathrm{m}}$ value was determined at $256 \mathrm{mM}$ (Filipkowski et al., 2012). It suggests an influence of this domain on enzyme activity. To examine the effect of the polyhistidine tag has on activity and kinetics of this protein we compared their properties to the wild-type enzyme (DgeoTreSW) from D. geothermalis expressed in E. coli Rosetta (DE3)pLysS. The region of D. geothermalis gene amplified by PCR had a sequence consisting of 1668 b.p. encoding 556 amino acid residues. Theoretical values of the molecular mass and isoelectric point of the wild-type enzyme were calculated to be $63.63 \mathrm{kDa}$ and $\mathrm{pI} 4.92$, respectively. These values estimated for the Dgeo'TreSW are slightly lower than those for Dgeo'TreS, due to the fact that the wild-type enzyme does not contain the $\mathrm{His}_{6}$-tag preceded by Leu (L) and Glu (E) residues.

An optimal expression was achieved at $30^{\circ} \mathrm{C}$ after $4 \mathrm{~h}$ of induction by IPTG (Fig. 1). The wild-type trehalose synthase has been preliminary purified by thermal precipitation of Escherichia coli proteins. This step removes $66.35 \%$ of native Escherichia coli proteins. What is more, specific activity of cell-free extract increases from 0.0159 up to $0.0416 \mu \mathrm{mol} / \mathrm{min} / \mathrm{mg}$. Solubilized recombinant trehalose synthase was precipitated at 20\% ammonium sulphate saturation. Dissolved precipitate was purified on a centrifugal filter device (Amicon Ultra-15 30000 MWCO). SDS/PAGE (Fig. 2) confirmed high purity of DgeoTreSW and their band was localized at the same place as his-tagged trehalose synthase. Among very intensive enzyme band only one weak band of other protein was visible. Such small amounts of other protein cannot influence the $K_{\mathrm{m}}$ value and their changes are caused by the polyhistidine tag.

\section{Effect of $\mathrm{His}_{6}$-tag on kinetic of maltose conversion}

Compared to the $K_{\mathrm{m}}$ of trehalose synthase with polyhistidine tag $(256 \mathrm{mM})$, the wild-type enzyme expressed in E. coli has a lower $K_{\mathrm{m}}$ of $170 \mathrm{mM}$. It suggests higher affinity of Dgeo'TreSW to maltose. Observed lower affin-

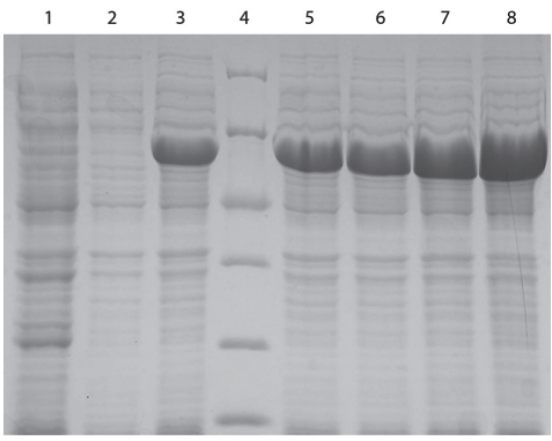

Figure 1. SDS/PAGE of protein in the fraction during the biosynthesis of the recombinant DgeoTreSW.

Lane 1, control E. coli strain with vector pET before induction; lane 2 , recombinant $E$. coli strain with vector before induction; lane 3 , cell extract after $3 \mathrm{~h}$ of protein expression induced by IPTG; lane 4 , protein marker (Fermentas \#SM0431); lane 5, cell extract after $4 \mathrm{~h}$ of protein expression induced by IPTG; lane 6 , cell extract after $5 \mathrm{~h}$ of protein expression induced by IPTG; lane 7, cell extract after $6 \mathrm{~h}$ of protein expression induced by IPTG; lane 8, cell extract after 18 $\mathrm{h}$ of protein expression induced by IPTG.

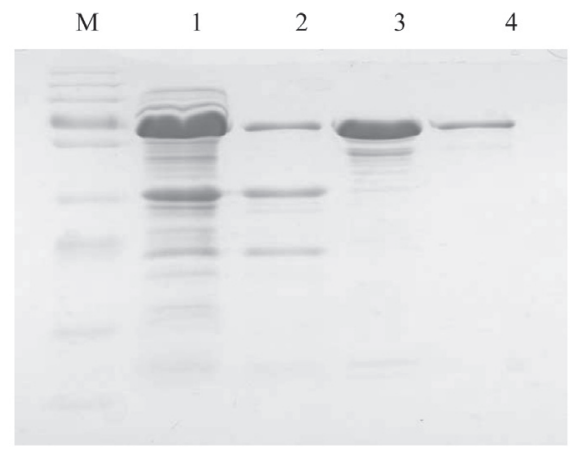

Figure 2. SDS/PAGE of proteins during the purification steps. Lane $M$, protein marker (Page Ruler ${ }^{\mathrm{TM}}$ Plus (Thermo Scientific. Line $1,10 \mu \mathrm{L}$ cell free extract cells of E. coli Rosetta (DE3) DgeoTreSW. Line $2,10 \mu \mathrm{L}$ of cell free extract after heat treatment at $65^{\circ} \mathrm{C}$ for $10 \mathrm{~min}$. Line 3, $10 \mu \mathrm{L}$ of protein fraction precipitated at $20 \%$ $\left(\mathrm{NH}_{4}\right)_{2} \mathrm{SO}_{4}$ and purified on Amicon ${ }^{\oplus}$, cut-off $100 \mathrm{kDa}$. Line 4, $10 \mu \mathrm{L}$ DgeoTreS protein after metal affinity chromatography.

ity of Dgeo'TreS to substrate may be a result of possible changes of enzyme conformations caused by the $\mathrm{His}_{6}$ tag. Recent reports also shown that His-tagged proteins are often expressed in E. coli, both in soluble form and insoluble inclusion bodies, limiting the amount of the enzyme accessible to the reaction (Halliwell et al., 2001; Terpe, 2003; Khan et al., 2012). According to the study of Khan et al. (2012) His-tag-free proteins have lower minima of CD spectrum at 208 and $222 \mathrm{~nm}$, as compared with their His-tagged counterparts. It indicates a higher amount of $\alpha$-helical content. Among the proteins investigated in our study, the catalytic efficiency $\left(k_{\text {cat }} / K_{\mathrm{m}}\right)$ value of Dgeo'TreSW was higher than that of DgeoTreS, indicating that Dgeo'TreSW is a better catalyst than trehalose synthase with the polyhistidine tag. The location of the hexa-histidine tag on the protein $\mathrm{N}$-terminus or C-terminus also can influence the protein activity. The study on DgeoTreS with $\mathrm{His}_{6}$-tag localized on the N-terminus is in progress and its results will appear elsewhere.

\section{Changes of reaction conditions caused by $\mathrm{His}_{6}$-tag}

Figure 3 shows that the optimal temperature of maltose conversion into trehalose catalyzed by Dgeo'TreS was $40^{\circ} \mathrm{C}$ and it was increased up to $45^{\circ} \mathrm{C}$ in case of the wild-type enzyme. The thermostability of Dgeo'TreSW was higher in comparison with the enzyme containing the polyhistidine tag. After $8 \mathrm{~h}$ of heating at $55^{\circ} \mathrm{C}$, the Dgeo'TreS retained about $57 \%$ of its maximal activity, whereas the Dgeo'TreSW was completely active $(100 \%)$ after $8 \mathrm{~h}$ of incubation.

In comparison with the wild trehalose synthase indicating maximal activity at $\mathrm{pH} 7.1$ in a $50 \mathrm{mM}$ Britton-

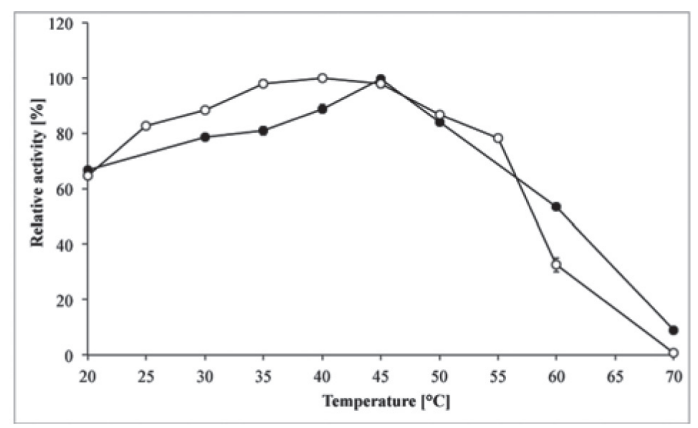

Figure 3. Optimal temperature of DgeoTreS $(\bigcirc)$ and DgeoTreSW ()) at $\mathrm{pH} 7.0$.

The results are mean values of three replicates. 


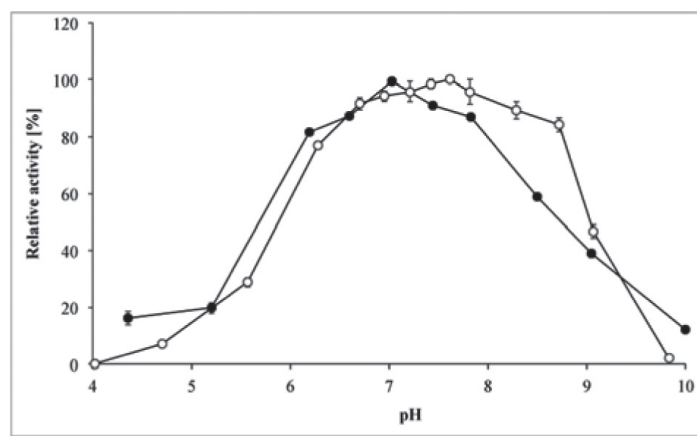

Figure 4. Optimal pH of DgeTreS (O) and DgeoTreSW (๑). The results are mean values of three replicates.

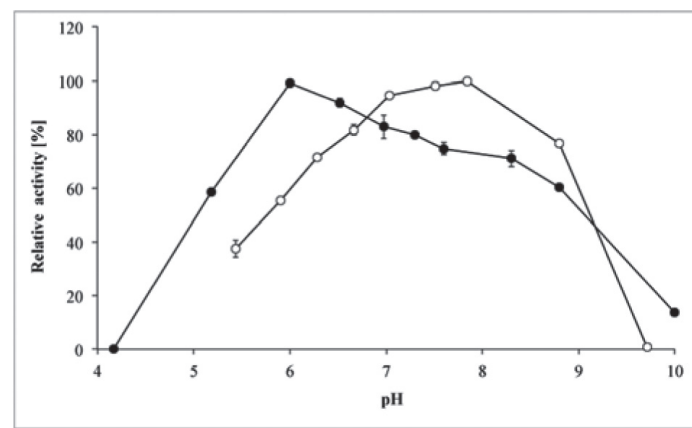

Figure 5. pH-stability of DgeoTreS $(\bigcirc)$ and DgeoTreSW (๑).

The $\mathrm{pH}$ stability was determined by measuring the residual activity after $1 \mathrm{~h}$ of incubation $\left(40^{\circ} \mathrm{C}\right)$ in $50 \mathrm{mM}$ Britton-Robinson buffers at various $\mathrm{pH}$ values. The results are mean values of three replicates.

Robinson buffer, the optimal $\mathrm{pH}$ for maltose conversion catalyzed by DgeoTreS was 7.6. These $\mathrm{pH}$ values are similar to those reported for trehalose synthases from Pimelobacter sp. R48 (Nishimoto et al., 1996a) and Thermus aquaticus (Nishimoto et al., 1996b). The investigated enzymes retained about $50 \%$ of maximal activity at a $\mathrm{pH}$ range of 6.0 to 9.0 (Dgeo'TreS), and 5.5 to 8.6 ( $D g$ eo'TreSW) (Fig. 4).

To determine the effect of $\mathrm{pH}$ level on the stability of trehalose synthases containing polyhistidine tag or enzyme without this domain, the samples were incubated for $1 \mathrm{~h}$ at different $\mathrm{pH}$ levels adjusted by Britton Robinson buffers. The DgeoTreS had the highest remaining activity when incubated at $\mathrm{pH} 7.7$, whereas the DgeoTreSW displayed maximal activity at the $\mathrm{pH}$ level of 6.0. Similarly to the Dgeo'TreS, the wild-type trehalose synthase was completely inactivated after the incubation at $\mathrm{pH}$ of about 4.2 and retained $85 \%$ of its maximal activity at the $\mathrm{pH}$ level of 7.0 (Fig. 5).

\section{CONCLUSION}

The present study leads to considerations about the influence of polyhistidine tags on kinetic parameters, and some properties of the recombinant trehalose synthase from $D$. geothermalis. The wild-type trehalose synthase exhibited higher activity when compared with his-tagged Dgeo'Tres, which had been studied previously. This report sends an important message that proteins containing His-tags may differ from their wild-type counterparts as far as their activity and other kinetic properties are concerned.

\section{Acknowledgments}

This work was financed mainly by the Polish National Science Centre.

\section{REFERENCES}

Benaroudi N, Lee DH, Goldberg AL (2001) Trehalose accumulation during cellular stress protects cells and cellular proteins from damage by oxygen radicals. I Biol Chem 276: 24261-24267.

Berendsen DH (2002) Trehalose: a review of properties, history of use and human tolerance, and resultes of multiple safety studies. Food Chem Toxicol 40: 871-898.

Crove JH and Crove IM (2000) Preservation of mammalian cells, Learning on nature tricks. Nat Biotechnol 18: 145-147.

Ferreira AC, Nobre MF, Rainey FA, Silva MT, Wait R (1997) Deinococcus geothermalis sp. Nov. and Deinococcus murrayi sp. Nov. two extremely radiation-resistant and slightly thermophilic species from hot springs. Int J Syst Bacteriol 47: 939-947.

Filipkowski P, Duraj-Thatte A, Kur JW (2006) Novel thermostable single-stranded DNA-binding protein (SBB) from Deinococcus geothermalis. Arch Microbiol 187: 129-137.

Filipkowski P, Panek A, Felczykowska A, Pietrow O, Synowiecki J (2012) Expression of Deinococcus geothermalis trehalose synthase gene in Escherichia coli and its enzymatic properties. Afr J Biotechnol 11: 13131-13139.

Filipkowski P, Pietrow O, Panek A, Synowiecki J (2012) Properties of ecombinant trehalose synthase from Deinococcus radiodurans expressem in Escherichia coli. Acta Biochim Pol 59: 425-431.

Halliwell CM, Morgan G, Qu CH-P Cass AEG (2001) Introduction of a (poly)histidine tag in L-lactate dehydrogenase products a mixture of active and inactive molecules. Anal Biochem 295: 257-261.

Higashiyama T (2002) Novel functions and applications of trehalose. Pure Appl Chem 74: 1263-1269.

Hochuli E, Debeli H, Schacher A (1987) New metal helate adsorbrnt selective for proteins and peptide containing neighbouring histidine residues. J Chromatogr 411: 177-184.

Jain KN, Roy I (2008) Effect of trehalose on protein structure. Protein Sci 18: 24-36.

Khan F, Legler PM, Mease RM, Duncan EH, Elke S, Bergman-Leitner Angov E (2012) Histidine affinity tags affect MSP1 $1_{42}$ structural stability and immunoobominance in mice. Biotechnol J 7: 133-147.

Laemmli UK (1970) Cleavage of structural proteins during the assembly of the head of bacteriophage T4. Nature 227: 680-685.

Lins RD, Pereira CS, Hünenberger PH (2004) Trehalose-Protein Interaction in Aqueous Solution. Proteins 55: 177-186.

Ma Y, Xue L, Sun DW (2006) Characteristic of trehalose synthase from permeabilized Pseudomonas putida cells and its application in converting maltose to trehalose. J Food Eng 77: 342-347.

Nishimoto T, Nakano M, Nakada T, Chaen H, Fukuda S, Sugimoto T, (1996a) Purification and properties of a novel enzyme, trehalose synthase from Pimelobacter sp. R48. Biosci Biotechnol Biochem 60: 640-644.

Nishimoto T, Nakada T, Chaen H, Fukuda S, Sugimoto T, KurimotoM (1996b) Action of thermostable trehalose synthase from Thermus aquaticus on sucrose. Biosci Biotechnol Biochem 60: 835-839.

Pan YT, Carrol JD, Asano N, Pastuszak I, Edavana VK, Elbain AD (2008) Trehalose synthase converts glycogen to trehalose. FEBS J 1275: 3408-3420.

Pietzsch M, Wiese A,Ragnitz K, Wilms B, Altenbuchner J, Mattes R, Syldatk C (2000) Purification of recombinant hydantoinase and LNcarbamoylase from Arthobacter aurescans expressed in Escherichia coli: comparison of wild-type and genetically modified proteins. J Chromatogr B 737: 179-186.

Richards AD, Krakowska S, Dexter LB, Schmid H, Wolterbeek APM, Waalkens-Roser B (1991) Trehalose, a new approach to premium dried foods. Trends Food Sci Technol 2: 166-169.

Terpe K (2003) Overview of tag protein fusions: from molecular and biochemical fundamentals to commercial systems Appl Microbiol Biotechnol 60: 523-533.

Wu J, Filutowicz M (1999) Hexahistidine (His $\left.{ }_{6}\right)$-tag dependent protein dimerization: A cautionary tale. Acta Biochim Polonica 46: 591-599.

Xiuli W, Hongbiao D, Ming Y, Yu Q (2009) Gene cloning, expression and characterization of a novel trehalose synthase from Artbrobacter aurescens. Appl Microbiol Biotechnol 83: 477-482.

Zdziebło A, Synowiecki J (2006) Production of trehalose by intramolecular transglucosylation of maltose catalyzed by a new enzyme from Thermus thermophilus. Food Chem 96: 8-13.

Zhu Y, Zhang J, Wie D, Wang Y, Chen X, Xing L, Li M (2008) Isolation and identyfication of a thermophilic strain producing trehalose synthase from geothermal water in China. Biosci Biotechnol Biochem 72: 2019-2024. 